\title{
Selenium and gastrointestinal cancers risk
}

\author{
Marcin Lener ${ }^{1 *}$, Anna Jakubowska ${ }^{1}$, Anna Wiechowska-Kozłowska², Józef Kładny³, Magdalena Muszyńska', \\ Grzegorz Sukiennicki', Jan Lubiński \\ From Annual Conference on Hereditary Cancers 2012 \\ Szczecin, Poland. 30-31 August 2012
}

Research suggests that selenium may influence the behavior of the cancer risk in two ways. As an antioxidant, selenium helps to protect the body against free radicals. Selenium may also prevent or slow tumor growth, as some breakdown products of selenium can inhibit tumor growth by enhancing immune cell activity and inhibition of tumor blood vessel development.

\section{Aim}

The aim of this study was to determine the level of selenium in blood serum as a potential marker of risk for cancers of the colon, stomach or pancreas.

\section{Material and methods}

The research material was a total of 110 samples of blood serum from people with cancer, diagnosed and confirmed in one of the organs: colon (67 cases), pancreas (30 cases) or stomach (13 cases) and 110 samples of blood serum derived from healthy individuals representing paired control group. The criteria adopted for pairing included: gender, year of birth $(+/-3$ years $)$, history of the occurrence of cancers in the family among first degree relatives and smoking status expressed in pack-years.

Selenium concentration in blood serum was determined using inductively coupled plasma mass spectrometry (ICP-MS) - Perkin Elmer. Validation: Seronorm ${ }^{\mathrm{TM}}$, Nycomed Pharma AS, Oslo, Norway. The measurement accuracy was $+/-5 \% \mu \mathrm{g}$ Se/l.

\section{Results}

Association between Se concentration and frequency of cancers in quartiles are presented in table 1. Statistical analyses are summarized in table 2 .

\section{Conclusions}

1. There is a very strong correlation between the level of selenium in serum and the risk of gastrointestinal cancers (pancreas, colon, stomach) in the Polish population.

2. Due to the risk of gastrointestinal cancers evaluated most people from the Polish population should increase

Table 1 Association between Se plasma concentration and risk of cancers analyzed.

\begin{tabular}{cccc}
\hline Cancer site & Quartile & Se concentration range $(\boldsymbol{\mu g} / \mathbf{l})$ & No. of Cases/ Contorls \\
\hline Pancreas & I & $25,69-50,09$ & $15 / 0$ \\
& II & $50,72-65,58$ & $9 / 6$ \\
& III & $66,34-73,30$ & $6 / 9$ \\
& IV & $74,07-113,89$ & $0 / 15$ \\
\hline Colorectal and stomach & I & $15,92-56,75$ & $35 / 5$ \\
& II & $57,3-67,91$ & $22 / 18$ \\
& III & $68,13-78,07$ & $12 / 28$ \\
\end{tabular}

'Department of Genetics and Pathology, Pomeranian Medical University,

Szczecin, Poland

Full list of author information is available at the end of the article 
Table 2 Results of statistical analyses of cancer site depending on Se concentration.

\begin{tabular}{|c|c|c|c|c|c|c|}
\hline \multirow[t]{2}{*}{ Cancer site } & \multirow[t]{2}{*}{ Quartiles compared } & \multirow[t]{2}{*}{ Se concentration range $(\mu g / l)$} & \multirow[t]{2}{*}{ Cases/controls in compared groups } & \multicolumn{3}{|c|}{ Fisher's Exact Test } \\
\hline & & & & $\mathbf{P}$ & OR & $\mathrm{Cl}$ \\
\hline \multirow[t]{3}{*}{ Pancreas } & | vs || & $25,69-50,09$ vs $50,72-65,58$ & $15 / 0$ vs $9 / 6$ & 0,017 & 21,2 & $1,07-421,1$ \\
\hline & | vs ||| & $25,69-50,09$ vs $66,34-73,30$ & $15 / 0$ vs $6 / 9$ & 0,0007 & 45,3 & $2,2-899,53$ \\
\hline & I vs IV & $25,69-50,09$ vs $74,07-113,89$ & $15 / 0$ vs $0 / 15$ & $<0,0001$ & 961 & 7,9-51,617 \\
\hline \multirow{3}{*}{$\begin{array}{l}\text { Colorectal } \\
\text { and } \\
\text { stomach }\end{array}$} & | vs || & $15,92-56,75$ vs $57,3-67,91$ & $(5) * 35 / 5$ vs $(4) * 22 / 18$ & 0,0026 & 5,7 & $1,86-17,66$ \\
\hline & | vs ||| & $15,92-56,75$ vs $68,13-78,07$ & $(5) * 35 / 5$ vs $(1) * 12 / 28$ & $<0,0001$ & 16,33 & $5,14-51,89$ \\
\hline & I vs IV & $15,92-56,75$ vs $78,38-155,72$ & $(5)^{*} 35 / 5$ vs $(3)^{*} 11 / 29$ & $<0,0001$ & 18,46 & $5,76-59,25$ \\
\hline
\end{tabular}

*stomach cancer cases

the level of selenium in serum to approximately 80-100 $\mu \mathrm{g} / \mathrm{l}$.

3. Prospective studies can elucidate:

a) the use of selenium measurements as markers of risk of above cancers,

b) possibility of lowering risk of the cancers of the colon, pancreas and stomach by supplementation of diet with selenium.

4. Assessment of the level of selenium may increase the effectiveness of many screening programs of gastrointestinal cancers, for example, the cost of detecting asymptomatic colorectal cancer by colonoscopy can be reduced dozen times.

Author details

${ }^{1}$ Department of Genetics and Pathology, Pomeranian Medical University, Szczecin, Poland. ${ }^{2}$ Laboratory of Endoscopy, Division of Health Care Ministry of Internal Affairs and Administration, Szczecin, Poland. ${ }^{3}$ Department of General and Oncological Surgery, Pomeranian Medical University, Szczecin, Poland.

Published: 10 December 2012

Submit your next manuscript to BioMed Central and take full advantage of:

- Convenient online submission

- Thorough peer review

- No space constraints or color figure charges

- Immediate publication on acceptance

- Inclusion in PubMed, CAS, Scopus and Google Scholar

- Research which is freely available for redistribution 